\title{
Pengaruh Etika Bisnis Terhadap Kepuasan Pelanggan Andayani Waroeng Steak N Djawa (Studi Pada Andayani Waroeng Steak N Djawa Di Pamekasan)
}

\author{
Berry Irsyad Al Amir
}

Jurusan Magister Manajemen Fakultas Ekonomi dan Bisnis Universitas Trunojoyo Madura

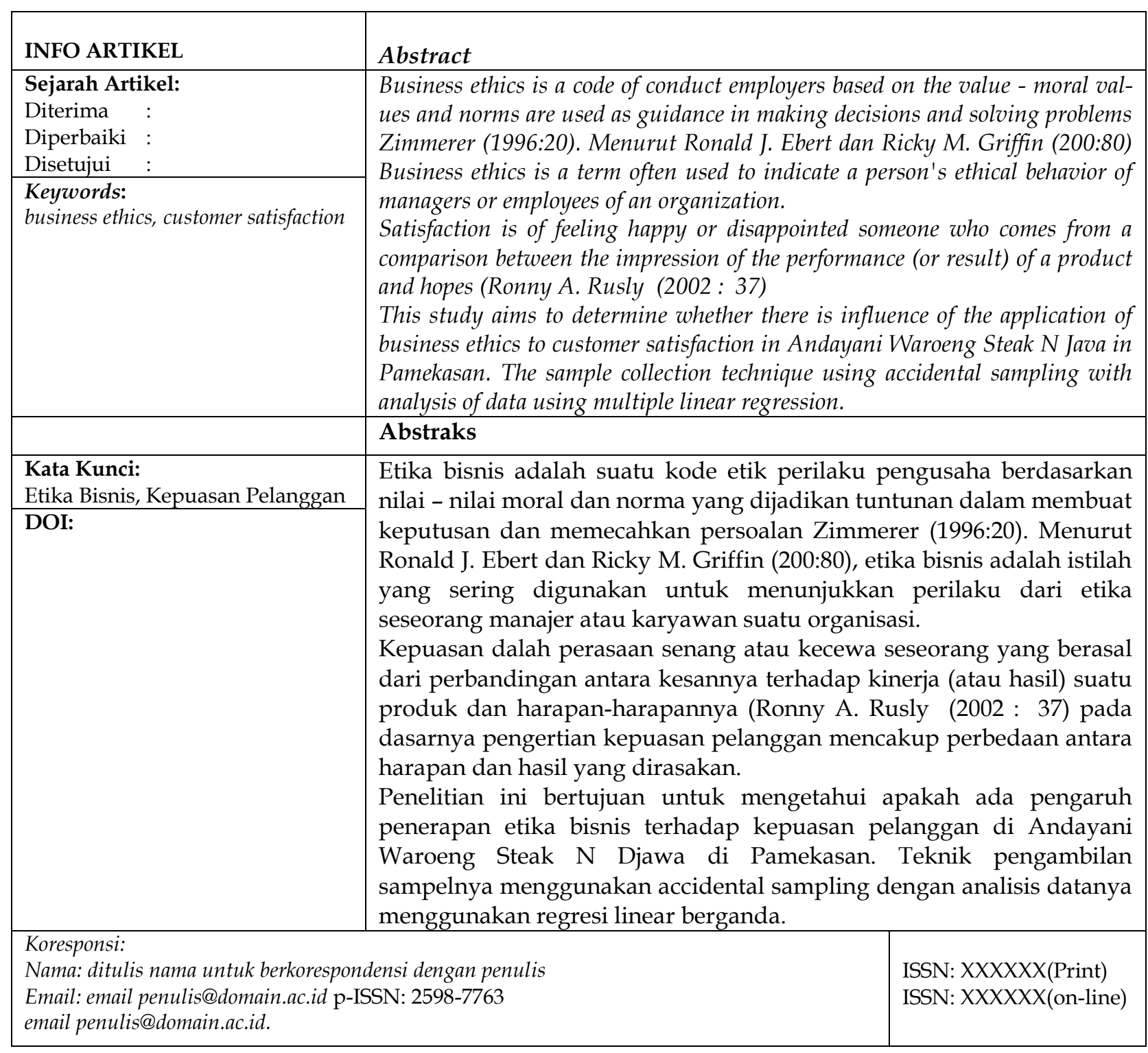




\section{PENDAHULUAN}

Semua keputusan perusahaan sangat memengaruhi dan dipengaruhi oleh pemilik kepentingan. Pemilik kepentingan adalah semua individu atau kelompok yang berkepentingan dan berpengaruh terhadap keputusan perusahaan. Ada dua jenis pemilik kepentingan yang berpengaruh terhadap perusahaan yaitu pemilik kepentingan internal dan eksternal. Menurut Ronald J. Ebert dan Ricky M. Griffin (200:80), etika bisnis adalah istilah yang sering digunakan untuk menunjukkan perilaku dari etika seseorang manajer atau karyawan suatu organisasi.

Ada dua jenis pemilik kepentingan yang berpengaruh terhadap perusahaan yaitu pemilik kepentingan internal dan eksternal. Pemilik kepentingan eksternal meliputi Investor, Karyawan, Manajemen, Pimpinan sedangkan Pemilik kepentingan internal meliputi Pelanggan, Asosiasi dagang, Kreditor, Pemasok, Pemerintah, Masyarakat umum Kelompok khusus yang berkepentingan terhadap perusahaan

Setiap perusahaan hidup dari pelanggannya, Karena itu pelanggan merupakan satu-satunya alasan keberadaan suatu perusahaan. Dengan demikian kepuasan pelanggan wajib menjadi prioritas setiap perusahaan. Berfokus pada pelanggan melalui usaha memahami kebutuhan, keinginan dan harapan mereka merupakan kunci memenangkan persaingan global yang demikian ketat.

Semakin banyaknya produsen yang menampilkan produk dan jasa, maka konsumen memilki banyak pilihan. Dengan demikian kekuatan tawar-menawar konsumen semakin besar.

\section{METODE}

Penelitian ini didesain dengan survey. Data penelitian yang dibutuhkan adalah data primer dalam bentuk persepsi responden (subjek) penelitian. Pengambilan data menggunakan survey langsung dan instrumen yang digunakan adalah kuisioner. Penelitian ini dilakukan pada pelanggan Andayani Waroeng Steak N Djawa di Pamekasan. Sampel yang dipilih melalui teknik accidental sampling. Teknik analisis data yang digunakan untuk menjawab rumusan masalah dalam penelitian ini adalah Analisis Regresi Linear Berganda.
Kepuasan dan ketidakpuasan pelanggan adalah respon pelanggan terhadap evaluasi ketidaksesuaian yang dirasakan antara harapan sebelumnya dalam kinerja aktual produk yang dirasakan setelah pemakaiannya. Maka dalam mencari sampai sejauh mana konsumen merasa puas atas jasa yang diberikan perusahaan tidak terlepas dari sesuatu yang diharapkan konsumen dan kenyataan yang diterima.

Setelah melakukan pembelian, konsumen akan merasakan suatu perasaan puas (satisfaction) atau tidak puas (dissatisfaction). Menurut (tripadvisior.com) Andayani Waroeng Steak N Djawa berada pada urutan ke 8 restoran terbaik di Pulau Madura dari 20 restauran.

Berdasarkan uraian permasalahan diatas, maka dapat dirumuskan permasalahan penelitian ini adalah sebagai berikut :

1. Adakah pengaruh etika bisnis terhadap kepuasan pelanggan Andayani Waroeng Steak N Djawa di Pamekasan?

2. Seberapa besar pengaruh etika bisnis terhadap kepuasan pelanggan Andayani Waroeng Steak N Djawa di Pamekasan? berikut :

Tujuan yang ingin dicapai adalah sebagai

1. Untuk mengetahui ada atau tidaknya pengaruh etika bisnis terhadap kepuasan pelanggan Andayani Waroeng Steak N Djawa di Pamekasan

2. Untuk mengetahui seberapa besar pengaruh etikabisnis terhadap kepuasan pelanggan Andayani Waroeng Steak N Djawa di Pamekasan.

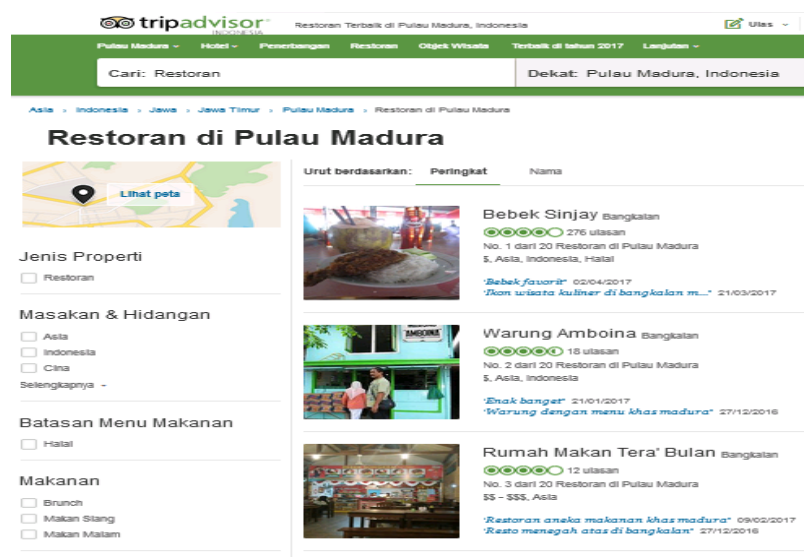




\section{HASIL DAN PEMBAHASAN}

\section{Uji Instrumen}

Instrumen yang digunakan dalam penelitian ini valid dan reliabel untuk dijadikan sebagai alat untuk meneliti pengaruh penerapan etika bisnis terhadap kepuasan pelanggan

\section{Uji Asusmi Klasik}

Uji asumsi klasik telah dilakukan, dan dari hasil uji statistik memenuhi syarat untuk dilanjutkan analisis regresi linear berganda.

\section{Analisis Regresi Berganda}

Pengujian statistik dengan alat analisis regresi linear berganda dimaksudkan untuk mengetahui pengaruh Kejujuran (X1), keadilan (X2), dan kepercayaan (X3) terhadap kepuasan pelanggan Rumah Makan Bebek Madu di kota Pamekasan. Adapun output dari penelitian dapat dilihat pada tabel 1 dibawah ini.

\begin{tabular}{|c|c|c|c|}
\hline \multirow{2}{*}{$\begin{array}{c}\text { Variabel } \\
\text { Independen }\end{array}$} & \multicolumn{2}{|c|}{$\begin{array}{l}\text { Unstandardized } \\
\text { Coefficients }\end{array}$} & \multirow[t]{2}{*}{ Befa } \\
\hline & B & Error & \\
\hline (Constant) & -0.532 & 0.451 & \\
\hline Kejujuran $\left(\mathrm{X}_{1}\right)$ & -0.126 & 0.122 & -0.096 \\
\hline Keadilan $\left(\mathrm{X}_{2}\right.$ & 0.191 & 0.131 & 0.136 \\
\hline Kepercayaan $\left(\mathrm{X}_{3}\right)$ & 1.059 & 0.065 & 0.937 \\
\hline R & $=0.925$ & & \\
\hline$R$ Square $\left(R^{2}\right)$ & $=0.855$ & & \\
\hline Adusted. $R$ Square & $=0.845$ & & \\
\hline F-nimuse & $=90.312$ & & \\
\hline Sign-F & $=0.000$ & & \\
\hline$S E$ & $=0.3944$ & & \\
\hline
\end{tabular}

Variabel Dependent - Kepuasan Pelanggan

Sumber : Data Diolah 2017

Persamaan regesi liner berganda sebagaimana pada ikhtisar ouput SPSS adalah :

$Y=-0.532-0.126 \mathrm{X} 1+0.191 \mathrm{X} 2+1.059 \mathrm{X} 3+$ 0.3944

Persamaan ini menunjukkan hal-hal sebagai berikut:

1. Konstanta sebesar 0.532 menunjukkan besarnya variabel kepuasan pelanggan jika kejujuran (X1), keadilan (X2), dan kepercayaan (X3) sebesar 0 (nol)

2. Variabel kejujuran (X1), memiliki nilai sebesar -0.126. hal ini menyatakan bahwa setiap satuan variabel kejujuran akan berpengaruh terhadap kepuasan pelanggan Andayani Waroeng Steak N Djawa -0.126 apabila variabel lainnya tetap. Namun disini variabel kejujuran bernilai negativ, artinya keadilan memiliki pengaruh yang berlawanan terhadap kepuasan pelanggan.

3. Variabel keadilan (X2), memiliki nilai sebesar 0.191. hal ini menyatakan bahwa setiap satuan variabel keadilan akan berpengaruh terhadap kepuasan pelanggan Andayani Waroeng
Steak N Djawa 0.191 apabila variabel lainnya tetap.

4. Variabel kepercayaan (X3), memiliki nilai sebesar 1.059. hal ini menyatakan bahwa setiap satuan variabel kepercayaan akan berpengaruh terhadap kepuasan pelanggan Andayani Waroeng Steak N Djawa 1.059 apabila variabel lainnya tetap.

5. Koefisien korelasi ( $R$ ) diperoleh sebesar 0.925 yang artinya bahwa hubungan antara variabel $X$ terhadap $Y$ sangat erat.

6. Koefisien determinasi (R2) diperoleh sebesar 0.855 yang artinya kontribusi variabel kejujuran (X1), keadilan (X2), dan kepercayaan (X3) $\backslash$ terhadap kepuasan pelanggan Andayani Waroeng Steak N Djawa di kota Pamekasan sebesar 85.5\%, sedangkan sisanya sebesar $14.5 \%$ kepuasan pelanggan Andayani Waroeng Steak N Djawa di kota Pamekasan dipengaruhi oleh faktor lain yang tidak diteliti dalam penelitian ini.

7. Koefisien determinasi yang telah disesuaikan (adjusted R2) diperoleh sebesar 0.845 yang artinya variasi perubahan nilai kepuasan pelanggan Andayani Waroeng Steak N Djawa di kata Pamekasan dapat dijelaskan melalui variabel kejujuran $_{0 .(X 1)}$, Keadilan (X2), Kepercayaan (X3) terhadap kepuasan pelanggan Andayani Waroeng Steak N Djawa sebesar $84.5 \%$ dan sisanya sebesar $15.5 \%$ dipengaruhi oleh variabel lain yang tidak diteliti dalam penelitian ini. Faktor-faktor lain yang mempengaruhi kepuasan pelanggan misalnya harga, rasa, pelayanan dan lain-lain.

\section{Uji Hipotesis (Uji F)}

Uji F digunakan untuk mengetahui pengaruh secara simultan variabel kejujuran (X1), keadilan (X2), dan kepercayaan (X3) terhadap kepuasan pelanggan Andayani Waroeng Steak N Djawa di kota Pamekasan.

Berdasarkan output SPSS nilai Fhitung = 90.312 dengan probabilitas 0.000 . kriteria pengujian menyatakan jika probabilitas hitung < level of signifance (@) maka H0 ditolak atau ada pengaruh signifikan secara simultan kejujuran (X1), keadilan (X2), kepercayaan (X3) terhadap kepuasan pelanggan (Y) Andayani Waroeng Steak N Djawa di kota Pamekasan.

Hasil pengujian menunjukkan $0.000<0.05$ atau probabilitas hitung < level of signifance (@) atau H0 ditolak. Hal ini berarti Kejujuran (X1), keadilan (X2), kepercaan (X3) secara simultan (bersama sama) berpengaruh terhadap kepuasan pelanggan (Y) Andayani Waroeng Steak N Djawa di kota Pamekasan.

Atas dasar analisis F-test tersebut maka hipotesis penelitian yang berbunyi terdapat 
pengaruh signifikan secara simultan kejujuran (X1), keadilan (X2), kepercayaan (X3) terhadap kepuasan pelanggan Andayani Waroeng Steak N Djawa di kota Pamekasan dapat diterima atau teruji kebenarannya.

\section{Uji hipotesis (Uji t)}

Uji $\mathrm{t}$ digunakan untuk menguji kebenaran hipotesis penelitian dilakukan dengan alat penguji signifikan t-test. Hal ini dimaksudkan untuk menguji signifikansi pengaruh secara sendirisendiri (parsial) variabel kejujuran (X1), keadilan (X2) dan kepercayaan (X3) terhadap kepuasan pelanggan Andayani Waroeng Steak N Djawa di kota Pamekasan.

1. Uji signifikan t-test antara kejujuran (X1) terhadap kepuasan pelanggan $(\mathrm{Y})$

Hasil analisis diperoleh nilai thitung kejujuran (X1) sebesar -0.126 pada tingkat probabilitas 0.305. kriteria pengujian jika probabilitas hitung $<$ level of signifance (@) maka H0 diterima. Hal ini berarti bahwa ada pengaruh yang tidak signifikan antara kejujuran (X1) terhadap kepuasan pelanggan (Y) Andayani Waroeng Steak N Djawa di kota Pamekasan

2. Uji signifikan t-test antara keadilan (X2) terhadap kepuasan pelanggan $(\mathrm{Y})$

Hasil analisis diperoleh nilai thitung kejujuran (X2) sebesar 0.191 pada tingkat probabilitas 0.152. kriteria pengujian menyebutkan jika probabilitas hitung < level of signifance (a) maka H0 ditolak atau ada pengaruh signifikan keadilan (X2) terhadap kepuasan pelanggan (Y) Andayani Waroeng Steak N Djawa di kota Pamekasan

3. Uji signifikan t-test antara kepercayaan (X3) terhadap kepuasan pelanggan $(\mathrm{Y})$

Hasil analisis diperoleh nilai thitung kepercayaan (X3) sebesar 1.059 pada tingkat probabilitas 0.000 . kriteria pengujian menyebutkan jika probabilitas hitung < level of signifance (@) maka H0 ditolak atau ada pengaruh signifikan kepercayaan (X3) terhadap kepuasan pelanggan (Y) Andayani Waroeng Steak N Djawa di kota Pamekasan. Hasil pengujian menunjukkan bahwa $0.000<0.05$ atau probabilitas hitung < level of signifance (a) sehingga H0 ditolak. Hal ini berarti bahwa ada pengaruh signifikan Kepercayaan (X3) terhadap kepuasan pelanggan (Y) Andayani Waroeng Steak N Djawa di kota Pamekasan

\section{SIMPULAN DAN SARAN \\ Kesimpulan}

Berdasarkan hasil penelitian, pembahasan, dan keterbatasan penelitian, maka dapat dikemukakan kesimpulan sebagai berikut:

1.Dimensi kejujuran dalam etika bisnis, berpengaruuh negatif dan tidak signifikan terhadap kepuasan pelanggan di Andayani Waroeng Steak N Djawa di kota Pamekasan

2.Dimensi keadilan dalam etika bisnis, berpengaruuh positif dan tidak signifikan terhadap kepuasan pelanggan di Andayani Waroeng Steak N Djawa di kota Pamekasan

3.Dimensi kepercayaan dalam etika bisnis, berpengaruuh positif dan tidak signifikan terhadap kepuasan pelanggan di Andayani Waroeng Steak N Djawa di kota Pamekasan

4.Penerapan etika bisnis dalam sebuah aktifitas bisnis memberikan pengaruh yang positif dan signifikan terhadap kepuasan pelanggan yang ada di Andayani Waroeng Steak N Djawa di kota Pamekasan.

\section{Saran}

Berdasarkan hasil penelitian, pembahasan dan keterbatasan penelitian, maka dapat disampaikan saran saran sebagai berikut:

1. Secara normatif agama menciptakan sistem makna untuk mengarahkan perilaku kesalehan dalam kehidupan manusia. Pendidikan agama harus mampu memenuhi kebutuhan dasar, yaitu memenuhi kebutuhan dasar, yaitu kebutuhan memenuhi tujuan agama yaitu memberikan kontribusi terhadap terwujudnya kehidupan religiuitas. Oleh karenanya untuk memahami konsep keberagaman secara utuh, tidak hanya cukup untuk tataran ritual/syariah saja.

2. Upaya menumbuhkembangkan sikap etis dalam berbisnis sehubungan dengan norma kerjanya yang dipandang sebagai suatu motifator dalam melaksanakan seluruh kegiatannya dalam seluruh aspek kehidupan. Oleh karenanya dibutuhkan suatu tindakan nyata dan kejujuran bersama untuk mencapai tujuan yang telah ditetapkan

3. Dalam menumbuhkan sikap yang berlandaskan nilai-nilai religiuitas dibutuhkan para pemimpin yang jujur dan berkeinginan memajukan organisasi. Religiuitas merupakan alternatif yang dapat dipilih untuk maksud tersebut.

4. Bagi pemilik usaha harus sering-sering mengadakan pelatihan dan motivasi kepada karyawannya untuk mampu memberikan pelayanan yang lebih baik kepada para pelanggan. 


\section{DAFTAR PUSTAKA}

Andreassen,W, Lindestad.B, 2008, Customer Loyalty and Complex Service TheImpact of Corporate Image on Quality, Customer Satisfaction andLoyalty for Customers With Varying Degrees of Service Expectise,International Journal of Service IndustryManagement, Vol 9.Iss.1.

Arikunto, Suharsimi. 2002. Edisi ke-lima. Prosedur Penelitian. Jakarta: Rineka Cipta

Aritonang,Lerbin, 2005,KepuasanPelanggan:PengukurandanPe nganalisisandenganSPSS, Jakarta: Penerbit Gramedia

Asy'arie, Musa, 1997. Islam: Etos Kerja dan Pemberdayaan Ekonomi Umat.Yogyakarta: LESFI \& IL

Bertens, K, 2000, Pengantar Etika Bisnis, Yogyakarta: Kanisius

Davidow, M, 2003. Organizational Responses To Customer Complaints: What Works And What Doesn't. Journal of Service Research.Vol. 5, No.3, pp. 225-250.

Davidow, M. 2003. Have You Heard The Word? The Effect of Word of Mouth on Perceived Justice, Satisfaction and Repurchase Intentions Following Complaint Handling. Journal of Consumer Satisfaction, Dissatisfaction and Complaining Behavior. Vol.16, pp. 67-79.

Edvardsson,B.,etal,2000,TheEffectsofSatisfactionan dLoyaltyonProfits andGrowth:ProductsvsServices,TotalQuality Management,Vol.11, No.7,pp.917-927.

Ferdinand, Augusty, 2006, MetodePenelitian Manajemen. Semarang: UNDIP Press

Fornell,

C,1992,ANational

CustomerSatisfactionBarometer:TheSwedish

Experience.JournalofMarketing,Vol.55,No.1(Januar y,pp.6-21).

Fornell, C,1996,TheAmerican CustomerSatisfaction Index:Nature, Purpose, and Findings. Journal of Marketing,Vol.60,No.4(October, pp.7-18).

Ghozali, Imam,2009,Aplikasi Analisis Multivariate dengan Program SPSS, Semarang: UNDIP Press

Hadi, Sutrisno, 1999, Metodologi Research. Yogyakarta: Penerbit Andi Kartawiria, Rajendra, 2004, Spiritualitas Bisnis, Bandung: Hikmah

Kau, A., Elizabeth, W. Loh. 2006. The Effects of Service Recovery on Consumer Satisfaction: a Comparison Between Complainants an
NonComplainants. Journal of Services Marketing.Vol. 20. No. 2, pp. 101-111.

Keraf, Sonny. 1998. "Etika Bisnis; tuntutan dan Relevansinya" Jakarta; Penerbit Kanisius.

Kotler, Philip,2005,ManajemenPemasaranJilid2. Jakarta: Penerbit INDEKS Kelompok Gramedia

Kotler,

Philip,BenyaminMolan,2005,ManajemenPem asaranJilid1. Jakarta: Penerbit INDEKS Kelompok Gramedia

Kotler, Philip, Gary Armstrong, 2008, Principles of Marketing Thirteenth Edition.New Jersey: Penerbit Pearson Education,Inc,

Lupiyoadi,Rambat,Hamdani,2006,

ManajemenPemasaranJasa. Jakarta: Penerbit Salemba Empat

Margaretha, Moureen, 2004, Studi Mengenai Loyalitas Pelanggan Pada Divisi Asuransi Kumpulan AJB Bumi Putera 1912 (Studi Kasus di Jawa tengah).Jurnal Sains Pemasaran Indonesia Vol 111, No. 3, Desember 2004, Hal 289-308.

Maxham, J. G., Richard, G. Netemeyer. 2002. Modeling Customer Perceptions of Complaint Handling Over Time: The Effects of Perceived Justice on Satisfaction and Intent. Journal of Retailing. Vol. 78, No.4, pp. 239-252.

Mowen Jc and M. Minor, 2002, Perilaku Konsumen Jilid kedua.Terjemahan dari Consumer Behaviour. Jakarta: Penerbit PT Erlangga

Mujiharjo, Bagyo, 2006, Analisis Faktor-faktor Yang Mempengaruhi Kepuasan Pelanggan dan Pengaruhnya Terhadap Loyalitas Pelanggan (Studi pada Bank BRI Demak). Jurnal Sains Pemasaran Indonesia, Vol V, No 2, Hal 193210.

Oliver,R,L,1997,"AcognitiveModelofTheAntecedent sandConsequences

ofSatisfactionDecisions",JournalofMarketing Research,Vol.17,No. 4,pp.460- 469.

Palupi,DyahHasto,MajalahSWA20/XX/30Septemb er-13Oktober2004.

Powers, T. L., and Dawn, B. 2002. Using Complaint Behavior to Improve Quality Through The Structure and Process of Service Delivery. Journal of Consumer Satisfaction, Dissatisfaction and Complaining Behavior, Vol.15, pp. 13-21.

Rahardjo, M. Dawam, 1990. Etika Ekonomi dan Manajemen. Yogyakarta: Tiara Wacana Yogya

Rangkuti,Freddy,2006,Measuring Customer 
Satisfaction:Teknik Mengukur dan Strategi Meningkatkan Kepuasan Pelangganplus Analisis Kasus PLNJP Jakarta: PenerbitGramedia

Sudarmadi, Dyah Hasto Palupi, Majalah SWA 24/XVII/ 22 November-2 Desember2001.

Sugiyono,2009,MetodePenelitianBisnis.Bandung: PenerbitAlfabeta

Suseno, Franz Magnis, 1987, Etika Dasar : Masalahmasalah Pokok Filsafat Moral, Yogyakarta: Kanisius

Sugiyono, 2004, Metode Penelitian Bisnis, Bandung, Alfabet.

Tasmara, Toto, 1995. Etos Kerja Pribadi Muslim, Jakarta: PT Dana Bhakti Wakaf

Tasmara, Toto, 2002. Membudayakan Etos Kerja yang Islami, Jakarta: Gema Insani Press

Taufiqullah, Zakat, Pajak Dan Ekonomi Islam, http://www.pikiranrakyat.com/prcetak/12 2001/04/0801.htm 10 April 2017.

Tax, Stephen S., and Stephen W. Brown, and Murali Chandrashekaran. 1998.Customer Evaluations of Service Complaint Experiences: Implications for relationship Marketing. Journal of Marketing. Vol. 62, No.2, pp. 60-76.

Tax, Stephen S., and Stephen W. Brown. 1998. Recovering and Learning From Service Failure. Sloan Management Review. Fall; Vol 40.No. 1, pp.75-88.

Tjiptono,Fandy,2006,PemasaranJasa.Malang: PenerbitBayumediaPublishing

Tjiptono,Fandy, Anastasia Diana, 2003, Total Quality Management. Yogyakarta: PenerbitAndi

Tjiptono,Fandy, Gregorius Chandra, 2005, Service, Quality \&Satisfaction.Yogyakarta: PenerbitAndi,
Triyuwono, Iwan, 2000. Organisasi Syari'ah, Yogyakarta: LKiS

Turner, Bryan S., Sosiologi Islam: Suatu Telaah Analitis Atas Tesa Sosiologi Weber, diterjemah oleh GA Tocialu, Jakarta: Rajawali Press

Trip Advisor, peringkat restoran di madura https://www.tripadvisor.co.id/reataurantsg1574414-Madura_Island_East_Java.html.

Diakses tanggal 13 April 2017

Tjiptono, Fandy, 1997, Manajemen Jasa, Yogyakarta, Andi.

Umar, Husein, 2002, Riset Pemasaran \& Perilaku Konsumen, Cetakan kedua, Jakarta, PT Gramedia Pustaka Utama.

Varela-Neira, C., Rodolfo, V.C., and Víctor, I. 2010. Explaining CostumerSatisfaction With Complain Handling. International Journal of Bank Marketing. Vol.26, No.2, pp. 88-112.

Wach, Joachim, 1958. The Comparative Study of Religion, New York: Columbia University Press

Weber, Max, 1958. The Protestant Ethic and the Spirit of Capitalism, translated by Talcott Parsons, New York: Charles Scribners

Weun, S, Sharon E.B., and Michael A.J. 2004. The Impact of Service Failure Severity on Service Recovery Evaluations and Post-Recovery Relationships. The Journal of Service Marketing. Vol.18,No.2,pp.133-146.

WJS Poerwadarminta, 2009.Kamus Umum Bahasa Indonesia, Jakarta: Balai Pustaka

Ya'kub, Hamzah, 1983. Etika Islam, Bandung: CV Diponegoro

Yusanto, M. Ismail \& Widjajakusuma, M. Karebet, 2002. Menggagas Bisnis Islami. Jakarta: Gema Insani Press 